\title{
Assessment of the psychometric properties of the Patient Satisfaction with Hospital Nursing Care Scale
}

\author{
Avaliação das propriedades psicométricas da Escala Satisfação dos Clientes com \\ os Cuidados de Enfermagem no Hospital \\ Evaluación de las propiedades psicométricas de la Escala de Satisfacción de los Pacientes \\ con los Cuidados de Enfermería en el Hospital \\ Maria João Baptista dos Santos de Freitas*; Pedro Miguel Dinis Parreira**; João Paulo Maroco Domingues***
}

\begin{abstract}
Background: Patient satisfaction with nursing care emerges as an important indicator for the assessment of the Structure and Process in the Results factors.

Objectives: Psychometric assessment of the Patient Satisfaction with Hospital Nursing Care Scale.

Methodology: Quantitative cross-sectional study with a sample of 1,290 patients.

Results: The confirmatory factor analysis did not show an acceptable goodness-of-fit of the original structure composed of 6 factors and 21 items. The several models assessed point to a 3-factor and 18-item structure $\left(\chi^{2}(130)=840.944 ; \chi^{2} /\right.$ $\mathrm{df}=6.469 ; p=.000 ; \mathrm{GFI}=.930 ; \mathrm{PGFI}=.707 ; \mathrm{RMSEA}=.065)$. Individually, the Quality of Care, Information Quality and Quality of Nursing Care factors are more comprehensive, covering the aspects included in the initial 6 factors. The final version of the scale showed a moderate to high reliability index $(\alpha=.875)$, explaining $71.5 \%$ of the total variance.

Conclusion: The psychometric study highlights an adequate final structure of the scale, with potential for identifying and monitoring patient satisfaction with nursing care.
\end{abstract}

Keywords: evaluation; nursing care; satisfaction; patient satisfaction

\section{Resumo}

Enquadramento: A satisfação dos clientes com os cuidados de enfermagem configura-se como um importante indicador de avaliação dos fatores de Estrutura e Processo nos Resultados. Objetivos: Avaliação psicométrica da Escala de Satisfação dos Clientes com os Cuidados de Enfermagem no Hospital.

Metodologia: Estudo quantitativo, transversal com uma amostra de 1290 clientes.

Resultados: A análise fatorial confirmatória não evidenciou qualidade de ajustamento aceitável da estrutura original composta por 6 fatores e 21 itens. Os diversos modelos avaliados apontam para uma estrutura composta por 3 fatores com 18 itens $\left(\chi^{2}(130)\right.$ $=840,944 ; \quad \chi^{2} / \mathrm{gl}=6,469 ; \quad p=0,000 ; \quad \mathrm{GFI}=0,930 ; \mathrm{PGFI}=0,707$; RMSEA $=0,065$ ).

Os fatores Qualidade dos Cuidados, Qualidade da Informação e Qualidade do Atendimento de Enfermagem são individualmente mais abrangentes, contemplando os aspetos dos 6 fatores iniciais. A versão final da escala apresentou um índice de fiabilidade moderada a elevada $(\alpha=0,875)$ explicando $71,5 \%$ da variância total.

Conclusão: O estudo psicométrico evidencia uma estrutura final da escala adequada, com potencial para investigação e monitorização da satisfação dos clientes com os cuidados de enfermagem.

Palavras-chave: avaliação; cuidados de enfermagem; satisfação; satisfação do paciente

\footnotetext{
* Ph.D., Guest Lecturer, Escola Superior de Enfermagem S. Francisco das Misericórdias, Rua de Santa Marta, $\mathrm{n}^{0}$ 56,1169-023 Lisboa, Portugal [mibsfreitas@gmail.com]. Contribution to the Santa Marta, $\mathrm{n}^{0} 56,1169-023$ Lisboa, Portugal [mjbsfreitas@gmail.com]. Contribution to the
article: participation in all research stages, article writing. Address for correspondence: Rua Horta da Cera ${ }^{\circ} 10$, Albarraque, Lisboa, Portugal.

** Ph.D., Adjunct Professor, Nursing School of Coimbra, 3046-851, Coimbra, Portugal. Contribution to the article: research guidance, article revision.

** Ph.D., Associate Professor, ISPA - Instituto Universitário de Ciências Psicológicas, Sociais e da Vida, 1149-041, Lisboa, Portugal. Contribution to the article: research co-guidance, data analysis.
}

\section{Resumen}

Marco conceptual: La satisfacción de los clientes respecto a los cuidados de enfermería supone un importante indicador en la evaluación de los factores de estructura y proceso en los resultados.

Objetivos: Evaluación psicométrica de la Escala de Satisfacción de los Pacientes con los Cuidados de Enfermería en el Hospital. Metodología: Estudio cuantitativo, transversal con una muestra de 1.290 pacientes.

Resultados: El análisis factorial confirmatorio no mostró una calidad aceptable del ajuste de la estructura original, compuesta por 6 factores y 21 ítems. Los diferentes modelos evaluados apuntan a una estructura compuesta por 3 factores y 18 ítems $\left(\chi^{2}\right.$ $(130)=840,944 ; \chi^{2} / \mathrm{gl}=6,469 ; p=0,000 ; \mathrm{GFI}=0,930 ; \mathrm{PGFI}=$ 0,707; RMSEA $=0,065$ ). Los factores Calidad de los Cuidados, Calidad de la Información y Calidad de la Atención de Enfermería son individualmente más amplios y contemplan los aspectos de los 6 factores iniciales. La versión final de la escala presentó un índice de fiabilidad moderado a alto $(\alpha=0,875)$, lo que explica el $71,5 \%$ de la varianza total.

Conclusión: El estudio psicométrico destaca una estructura final de la escala adecuada con potencial para la investigación y monitorización de la satisfacción de los pacientes con los cuidados de enfermería.

Palabras clave: evaluación; cuidados de enfermeira; satisfacción; satisfacción del paciente

Received for publication: 13.04 .16 Accepted for publication: 26.07 .16 


\section{Introduction}

Patient satisfaction is a valuable indicator of quality, both in health in general and in nursing care in particular. Patients are assigned the responsibility of issuing judgments, based on their perceptions, concerning the care that they received, for example during their hospital stay.

Although the concept of satisfaction is multidimensional and involves a wide range of dimensions and constraints, there is some consensus about its definition: the result of the differences between patients' expectations about care and their perceptions of the care actually received (Ribeiro, 2003; Fernandes, Seco, \& Queirós, 2009). Therefore, patients' opinion is essential for monitoring the quality of nursing care. It is also important to use valid and reliable measurement instruments. To this end, the general objective of this study was to assess some psychometric properties of the Escala de Avaliação da Satisfação dos Utentes com os Cuidados de Enfermagem no Hospital (SUCEH21; Patient Satisfaction with Hospital Nursing Care Scale) developed by Ribeiro (2003).

\section{Background}

The assessment of patient satisfaction with nursing care incorporates various dimensions that reflect the care provided and the setting where it is provided. However, this is a complex process to the extent that the several actors involved (patients, nurses, organization managers) have different perspectives about the standards of quality of care and the value individually assigned to each dimension of satisfaction (Paz, Parreira, Lobo, Palasson, \& Farias, 2014).

Although the concept of satisfaction and the identification of its dimensions have been studied by multiple researchers, no consensus has been reached. However, it is possible to find common aspects concerning both its concept and its dimensions. Therefore, patient satisfaction is mostly related to the presence of technical and scientific skills characterized by the quality of the action, the communication and the information conveyed (Ribeiro, 2003), relational/communicational skills and the continuity/organization of care (Pereira, Araújo-
-Soares, \& McIntyre, 2001; Ribeiro, 2003; Silva, 2013). As a professional activity, nursing values the relationship established between nurses and patients/ family in the care process, which is also one of the most valued and recognized aspects by the patients. Therefore, nurses should focus on the quality of the relationships established with their patients, on how they communicate and inform, and on their availability, without neglecting other issues inherent to the care environment.

Donabedian (2003) developed a 3-component model for assessing the quality of health care: Structure, Process and Outcomes, which is used as a reference to ensure quality in health. This model enabled the development of models for the assessment of nursing care quality and the satisfaction of patients with the care received. This model conceptualized Structure as being the environment where care is provided (facilities, material and human resources, organization and safety of services, relational/ organizational climate), Process as being the set of interventions performed by nurses, and Outcomes as being the fulfilment of the patients' needs. Structure and Process are interrelated to condition Outcomes, which requires that measurement instruments, particularly those used to assess patient satisfaction, include dimensions of satisfaction associated with each one of these elements.

Ribeiro (2003) took into account the Structure and Process factors in designing the scale to assess patient satisfaction with nursing care, and integrated six dimensions of satisfaction: Therapeutic Environment Maintenance (TEM) and Readiness to Assist (RA) as Structure-related factors; Communication Effectiveness (CE), Information Usefulness (IU), Assistance Quality (AQ) and Promotion of Care Continuity (PCC) as Process-related factors.

In view of the above, we formulated the research question below.

\section{Research question}

To what extent does the Escala de Avaliação da Satisfação dos Utentes com os Cuidados de Enfermagem no Hospital (SUCEH21) shows adequate psychometric properties to assess patient satisfaction with nursing care received during hospital stay? 


\section{Methodology}

We performed a cross-sectional analytical-correlational study (Grove, Burns, \& Gray, 2013) with the purpose of analyzing the psychometric properties of the SUCEH21 scale.

The following inclusion criteria were determined: patients admitted to inpatient units, with different profiles (Medicine, Surgery, Obstetrics and Pediatrics), and hospital length-of-stay of more than 24 hours. We obtained a total of 1,290 participants (30 per service) from 43 inpatient units.

\section{Data collection tool}

We used the SUCEH21 form developed by Ribeiro (2003). This form was designed to obtain demographic data, as well as information on the frequency of nurses' interventions and the level of satisfaction/ dissatisfaction with nurses' interventions (Hill \& Hill, 2009).

The CE dimension includes three questions on nurses' behavior when transmitting information, and integrates items that reflect how patients experience the communication process with nurses during their hospital stay.

The IU dimension includes five questions on the information transmitted by nurses to allow patients to cope with their situation, and includes items that identify how patients implement or maximize the information received.

The AQ dimension includes five questions on patients' satisfaction with care received from admission to discharge.

The PCC dimension includes two questions on nurses' concern with the family's involvement in understanding and collaborating in care provision, and in the post-discharge care process.

The TEM dimension includes four questions on the management of the physical environment (comfort, privacy, among others) by nurses during hospital stay, promoting a therapeutic environment.

Finally, the RA dimension includes two questions, which reflect the product of the relationship between nurses' availability toward patients and their ability to respond in a timely manner to patients' requests when they need support.

The scale has a total of 21 items.

\section{Procedures}

After permission was granted by the scale's author and the institutions involved, we conducted meetings with all nursing directions and head nurses to explain the study (purpose, rationale, objectives, data collection tools). We agreed that the control of the form distribution and collection process would be performed by head nurses in their units, based on the timeline presented.

In this study, all ethical principles regarding the respect for human dignity were met. Respondents decided to participate in the study and were provided information on the topic, scope, purpose and objectives of the study. In the case of pediatric patients and adult patients unable to self-report, we took into account the opinion of the closest caregiver who was more present during the hospital stay. Anonymity, privacy and confidentiality were ensured since no personal data that could identify the respondents were collected, and the answers were subsequently encoded.

Data were analyzed using descriptive statistics (measures of central tendency, dispersion and frequency). To assess the psychometric characteristics of the SUCEH21 scale, we first used the confirmatory factor analysis (CFA), since the form and its dimensionality (number of factors) had been previously analyzed. Thus, we sought to confirm its factor structure, assessing its goodness-of-fit to the correlational structure observed between variables (Marôco, 2014). In view of the results obtained, we used the exploratory factor analysis (EFA) in order to find a factor structure that explained the correlations between latent and manifest variables, allowing for the reconstruction of the measurement scale adjusted to the study sample (Marôco, 2011). The software used for data analysis was IBM Statistical Package for the Social Sciences (SPSS), version 21 and IBM SPSS AMOS® (version 22).

\section{Results}

The sample $(n=1290)$ consisted of 724 female participants (56.1\%) and 566 male participants (43.9\%). The mean age was 54 years, ranging between 14 years and 98 years, with a standard deviation of 
20.06 years and a median of 55 years. Approximately $56.5 \%$ of the patients had basic education, 22.6\% had secondary education, and $20.9 \%$ had a higher education degree.

\section{Confirmatory Factor Analysis}

The generated factor models were assessed in terms of the quality with which they reproduce intervariable correlations, by calculating the goodness-of-fit indices ( $\mathrm{X}^{2} /$ degrees of freedom (df), GFI, Parsimony Goodness-of-Fit Index (PGFI), Comparative Fit Index (CFI), Parsimony Comparative Fit Index (PCFI), Root Mean Square Error of Approximation (RMSEA) as recommended by Marôco (2014). The model consists of six factors and 21 items adjusted to the sample of 1,290 users showed an unacceptable goodness-of-fit $\left(\chi^{2}(176)=5050.132 ; p=.000 ; \chi^{2} / \mathrm{df}=28.694\right.$; $\mathrm{GFI}=.765$; PGFI $=.583$; RMSEA $=.147$ ), so it was necessary to make adjustments.
After removing items with factor loadings below .5 (CE.3 and TEM.4), correlating errors of some items (e25-e26, e23-e24, e10-e11, e9-e11) and removing items whose modification indices suggested loading on different factors from those suggested in the original version, we obtained a 5 -factor structure: IU (5 items), AQ (5 items), RA (2 items), MAT (3 items) and PCC (2 items). The simplified model showed a good quality of goodness-of-fit $\left(\chi^{2}(104)=1157.231\right.$; $p=.000 ; \chi^{2} / \mathrm{df}=11.127 ; \mathrm{GFI}=.905 ; \mathrm{PGFI}=.615 ;$ RMSEA $=.089$ ), which is significantly higher than that of the original model. However, the results of the model were not valid because the covariance matrix was not positive. The resulting final model was composed of three factors and 18 items, revealing acceptable indices: $\chi^{2}(130)=840.944 ; \chi^{2} / \mathrm{df}=6.469$; $p=.000$; GFI $=.930$; PGFI $=.707$; RMSEA $=.065$, as shown in Figure 1.

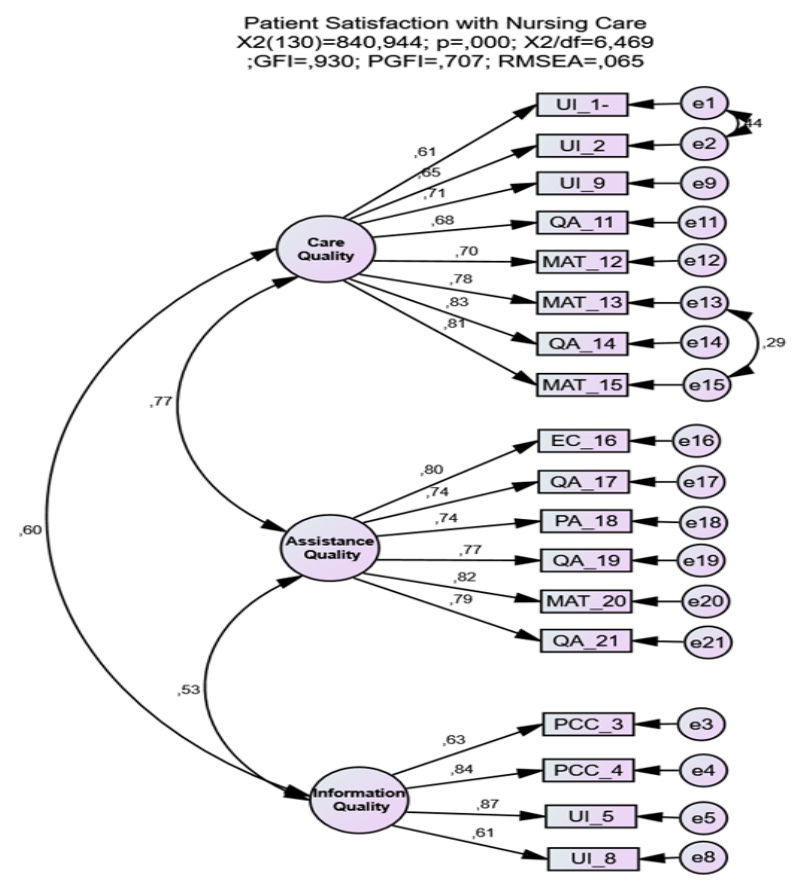

Figure 1. Confirmatory factor model of de Patient Satisfaction with Nursing Care.

No studies were found on the psychometric validation of the SUCEH21 scale which could be compared to the structure above presented. Although previous studies have used this instrument to assess patient satisfaction with nursing care (Ferreira, 2011; Macedo, Moreira, \& Moreira, 2012; Varandas \& Lopes, 2012), they only mention Cronbach's $\alpha$ values of internal consistency and its validity through the total variance explained.

\section{Exploratory Factor Analysis}

Based on the results obtained, we chose to study the factor structure and the validity of the SUCEH21 scale using the EFA technique, which was performed using 
the principal components analysis with orthogonal Varimax rotation, followed by the assessment of the internal consistency (reliability) using Cronbach's $\alpha$ coefficient. The following criteria were used to select the factors to be retained: eigenvalue greater than 1 , minimum number of factors that explain $50 \%$ of the total variance of the original variables, scree plot, variance of each factor being $5 \%$ of the total variance, and minimum factor loading of .50 for each item (Marôco, 2011). Finally, we used Pearson's correlation coefficient $(r)$ to assess correlations between items, factors and the scale.

Before starting the EFA, we assessed the sample adequacy using the Kaiser-Meyer-Olkin (KMO) measure. A value of .95 was obtained, which, according to Pestana and Gageiro (2008), is considered to be very good with significance for Bartlett's test of sphericity $\left(X^{2}=15752.988, p<.001\right)$. This allowed us to proceed with the principal components analysis. The analysis revealed three factors with eigenvalues greater than 1 , which explained $64.56 \%$ of the total variance (F1: 49.26\%; F2: 8.53\%; F3: 6.76\%). Marôco (2011) considered it as being above the minimum acceptable value. The scree plot criterion confirms this result with the inflection of the curve between the factors 3 and 4 .

Given that the author of the scale extracted six factors meeting the above-mentioned criteria, we performed a principal components analysis forced to six factors with orthogonal Varimax rotation. We obtained eigenvalues less than 1 in factors 4, 5 and 6, explaining $74.65 \%$ of the total variance. According to Marôco (2011), the criterion for the retention of factors whose individual contribution to the total variance explained should be at least $5 \%$, which could justify the inclusion of factors 4 and 5 . However, factor 6 did not meet this criterion, so its inclusion could only be supported by the theoretical framework. Thus, we decided to retain three factors that fulfilled all criteria, having obtained a structure composed of 18 items (items 6 and 7 were excluded by abandoning the theoretical factor to which they belonged - Information Quality, as well as item 10 for having a very low factor loading (.34 which explained $71.50 \%$ of the total variance). The individual contribution of the factors was as follows:
F1-24.13\%; F2-18.43\% and F3-22.89\% for the total variance explained. Three factors have emerged:

Factor 1 - Care Quality (CQ) brings together items that illustrate how patients perceive the effectiveness of the communication process, including the maximization of the information transmitted and the effectiveness of the care process, taking into account aspects such as personalization of care, respect for privacy and personal characteristics and needs, promotion of well-being, and readiness of assistance. Factor 2 - Information Quality (IQ) brings together items that reflect the relevance and usefulness of the information transmitted to the patient during hospital stay, with the purpose of providing patients with the necessary skills to cope with their illness/health condition during hospitalization and after discharge.

Factor 3 - Assistance Quality (AQ) consists of items that express patient satisfaction/dissatisfaction regarding aspects such as nurses' ability to convey clear information, listening skills, ability to solve problems in a timely manner, ability to respond to patients' needs, and technical competence.

These three factors make up 18 of the 21 items from the original scale, reflecting the six factors proposed by the author of the scale.

All items that loaded on their factors have positive factor loadings. CQ, IQ and AQ factors are representative of the Patient Satisfaction with Nursing Care (Satisfação dos Clientes com os Cuidados de Enfermagem - SCCE) construct. Therefore, we found that the higher the quality of assistance, the information transmitted and nursing care, the higher the patients' overall satisfaction with nursing care.

In the next phase, we analyzed reliability through the assessment of internal consistency by calculating Cronbach's $\alpha$ coefficient, considered as an estimate of reliability suitable in most cases (Marôco \& Garcia-Marques, 2006). In this study, we obtained the following Cronbach's $\alpha$ coefficients for each factor: $\mathrm{F} 1=.90, \mathrm{~F} 2=.82$, and $\mathrm{F} 3=.91$, showing moderate to high reliability in the CQ, IQ dimensions, and high reliability in the AQ dimension (Marôco \& Garcia-Marques, 2006). Table 1 illustrates the results described. 
Table 1

SCCE Scale - \% of variance explained and eigenvalues per factor, factor solutions, internal consistency by factor

\begin{tabular}{|c|c|c|c|}
\hline \multirow{2}{*}{ Items/ Description } & $\begin{array}{l}\text { F1-CQ } \\
24.13 \% \\
\end{array}$ & $\begin{array}{c}\text { F2-IQ } \\
18.48 \% \\
\end{array}$ & $\begin{array}{l}\mathrm{F} 3-\mathrm{AQ} \\
22.89 \% \\
\end{array}$ \\
\hline & $\begin{array}{c}\text { Eigenvalue } \\
4.34\end{array}$ & $\begin{array}{c}\text { Eigenvalue } \\
3.33\end{array}$ & $\begin{array}{c}\text { Eigenvalue } \\
4.12\end{array}$ \\
\hline CQ13 - Did you feel that nurses were kind to you & .78 & & \\
\hline CQ15 - Do you think that nurses were patient when providing care to patients & .78 & & .30 \\
\hline CQ14 - Did you feel that nurses took interest in your problems & .75 & & .34 \\
\hline CQ11 - Were nurses concerned with keeping your privacy when providing care & .73 & & \\
\hline $\begin{array}{l}\text { CQ12 - While providing care, nurses were concerned with keeping a quiet } \\
\text { environment }\end{array}$ & .69 & & \\
\hline $\begin{array}{l}\text { CQ2 - Did you feel that nurses were concerned with teaching you what you } \\
\text { needed to know to deal with your nursing care needs }\end{array}$ & .58 & .45 & \\
\hline $\begin{array}{l}\text { CQ1 - Did nurses provide you with all the information you thought was neces- } \\
\text { sary to deal with your nursing care needs }\end{array}$ & .55 & .41 & \\
\hline $\begin{array}{l}\text { CQ9 - Were nurses concerned with explaining to you the care you were receiv- } \\
\text { ing and the reason why they had to perform them }\end{array}$ & .55 & .48 & \\
\hline AQ21 - With regard to nurses' knowledge of the care you needed & & & .78 \\
\hline $\begin{array}{l}\text { AQ20 - With regard to nurses' availability to listen to you or even to solve any } \\
\text { service-related situation }\end{array}$ & & & .78 \\
\hline $\begin{array}{l}\text { AQ19 - With regard to nurses' concern with preserving your intimacy when } \\
\text { providing care }\end{array}$ & .32 & & .76 \\
\hline AQ17 - With regard to how you were welcomed by nurses at the hospital & & & .75 \\
\hline $\begin{array}{l}\text { AQ16 - With regard to how nurses explained things, the language they used, } \\
\text { their concern with repeating things if you did not understand them, their } \\
\text { concern with knowing if you had really understood them }\end{array}$ & & & .74 \\
\hline AQ18 - With regard to the time that nurses took to meet your requests & & & .70 \\
\hline $\begin{array}{l}\text { IQ5 - Were nurses concerned with conveying information on how to use the } \\
\text { available health services (how and when to use them) }\end{array}$ & & .84 & \\
\hline $\begin{array}{l}\text { IQ4 - Were nurses concerned with conveying information on the services avail- } \\
\text { able (e.g., consultations, support services...) }\end{array}$ & & .82 & \\
\hline $\begin{array}{l}\text { IQ8 - Were nurses concerned with providing you written information on the } \\
\text { topics that they addressed (leaflets, books or even writing down things that are } \\
\text { important to you) }\end{array}$ & & .71 & \\
\hline $\begin{array}{l}\text { IQ3 - With regard to the information, were nurses concerned with engaging } \\
\text { your relatives or closest persons (explaining your situation and how they could } \\
\text { help you whenever you needed) }\end{array}$ & & .66 & \\
\hline Cronbach's alpha & .90 & .82 & .91 \\
\hline
\end{tabular}

\section{Correlational study}

The inter-item validity and the item-factor validity, through the assessment of Pearson's correlation, revealed moderate to high inter-item correlations in Factor 1 (CQ; ranging between a minimum correlation value of .428 - moderate correlation - and a maximum correlation value of.744 - high correlation (Pestana \& Gageiro, 2008). Item-factor correlations are high.

Inter-item correlations in Factor 2 (IQ) are moderate, and item-factor correlations are Inter-item correlations in Factor 3 (AQ) are mostly moderate, while item-factor correlations are high.
The correlations observed between items and the different factors are higher between the items and the factor to which they theoretically belong than in other factors. These results show the content homogeneity of the items in the factor to which they belong, thus confirming construct validity.

Through Pearson's correlation matrix, we assessed the relationship between the three factors of the scale and the total scale, as shown in Table 2. We found strong significant correlations, for a significance level of $p<.01$, between the three factors (AQ, IQ, CQ), the lowest being between IQ 
and $\mathrm{AQ}(\mathrm{IQ} \leftrightarrow \mathrm{AQ}=.61)$ and the highest between $\mathrm{CQ}$ and $\mathrm{AQ}(\mathrm{CQ} \leftrightarrow \mathrm{AQ}=.85)$. The correlations between the three factors and the total scale are positive, high and significant $(r=.75)$.

Table 2

Pearson's correlation between the components of patient satisfaction with nursing care and the SCCE construct

\begin{tabular}{lcccc}
\hline & CQ & IQ & AQ & EASCCE18 \\
\hline CQ & 1 & $.65^{* *}$ & $.856^{* *}$ & $.89^{* * *}$ \\
IQ & 1 & $.61^{* * *}$ & $.89^{* *}$ \\
AQ & & 1 & $.85^{* *}$ \\
EASCCE & & & 1 \\
**. Correlation set at $p<.01$ & & &
\end{tabular}

**. Correlation set at $p<.01$

These results confirm the construct validity of the Escala de Avaliação da Satisfação dos Clientes com os Cuidados de Enfermagem, which is composed of three factors that integrate all components relating to the six factors/dimensions proposed in the original scale, with a total of 18 items.

\section{Discussion}

Patient satisfaction is currently a key topic in every evaluation process. This process requires special attention from health professionals because, as Ferreira, Pontes, e Ferreira (2009) argues, the quality of care largely depends on the quality of the nursepatient relationship. A hospital environment is an arena of relationships. The expectations toward hospitalization, treatment and quality of care vary from person to person, hence it is important to assess the level of satisfaction. They result from people's beliefs, values, the environment in which they are inserted and the information that they already have. Therefore, satisfaction is understood as being something personal and individual (Fernandes, Seco, \& Queirós, 2009). The identification of patients' level of satisfaction allows aligning the organization's strategy with the patients' needs, thus creating gains for the different stakeholders (Porter, Pabo, \& Lee, 2013). This whole process calls for the use of valid and reliable instruments. Among several instruments, Pereira, Araújo, Soares, and McIntyre (2001) refer to the review of 41 studies carried out by Roter (1989), who found that the most important factors for patient satisfaction were the information conveyed about the disease, treatment and care, and the communication established between professional and patient. In addition, Paz et al. (2014) underline and emphasize these factors in the assessment of patient satisfaction regarding nursing interventions in primary health care.

The purpose of this study was to investigate, using confirmatory techniques, the psychometric properties of the SUCEH21 scale.

The use of CFA allowed obtaining a 3-factor structure which corroborates the multidimensionality of the SUCEH21 scale developed by Ribeiro (2003). However, although we have not confirmed the structure proposed by the author (composed of six factors), we obtained a three-factor structure that is consistent in terms of item content and adequate factor loadings, resulting in a simplified version of the number of factors (Care Quality, Information Quality and Assistance Quality). In general, the structure maintains the vast majority of original items (only three items were removed), showing adequate goodness-of-fit indicators.

The fact that we have not been able to reproduce the original structure may be due to various reasons, ranging from the different characteristics of the samples to the criteria used for factor retention. The literature points out that there is often no consensus on the factor structure (Damásio, Machado, \& Silva, 2011). To this regard, Laros (2005) reports the overestimation or underestimation of the number of factors to be retained in factor analyzes based on different assumptions as the major cause of discrepancy between structures. With regard to sample size, we met the criteria for the EFA based on the proposal by Laros (2005), who considers it to be an excellent solution when more than 1,000 answers are obtained. In this study, we obtained 1290 answers. In terms of studies conducted by other researchers 
using the SUCEH21 scale, we underline several national studies (Ribeiro, 2003; Ferreira, 2011; Macedo, Moreira, \& Moreira, 2012; Varandas \& Lopes, 2012). However, since they make no reference to dimensions of satisfaction and did not assess the structure through EFA or CFA, we were not able to make comparisons. We are no aware of any international studies on this topic.

These results reinforce the need to continue to assess the dimensionality of the instrument with other samples in order to compare results. We are faced with the need to conduct studies that assess the factor structure of the Satisfação dos Clientes com os Cuidados de Enfermagem construct.

Despite the contribution of this research to assess the structure of the instrument and its psychometric properties, it is important to note some limitations. The first limitation is based on the fact that data were collected through a convenience sample (Hill \& Hill, 2005). We cannot confirm the representativeness of the sample since we did not compare the sample profile with the population profile given the difficulties in collecting such indicator. Thus, we cannot generalize the findings to the Portuguese population. Another limitation was the fact that we did not analyze its convergent and discriminant validity.

We recommend that further studies should be conducted to assess temporal stability. The development of studies assessing its convergent validity by assessing other constructs would allow identifying patients' satisfaction and its association with other dimensions.

We suggest that the study of the psychometric properties of the scale in different contexts and different groups should continue with the purpose of assessing its dimensionality. We also suggest the development of longitudinal studies with different constructs so as to assess the evolution of the level of satisfaction over a given period, and contribute to a better understanding of the variations in patient satisfaction based on their level of satisfaction and associated factors.

\section{Conclusion}

The initial objective of this study was to assess the psychometric properties of the SUCEH21 scale. In view of the results obtained, we presented a new version with a valid and reliable structure for this measurement instrument. The validation studies performed through CFA and EFA techniques revealed a 3-factor structure (Care Quality, Information Quality and Assistance Quality), which contrasts with the six-factor structure proposed by the author (Ribeiro, 2003). After assessing the factor structure found in the EFA, we observed that the three factors are individually more comprehensive, covering aspects that constitute the six initial factors. The results allow us to conclude that the scale has adequate psychometric properties, as shown by Cronbach's $\alpha$ reliability coefficients (.875), which are higher than in the original scale, and validity coefficients, with $71.5 \%$ of the total variance explained, which is also higher than that obtained in the psychometric study of the original SUCEH21 scale.

Since the SCCE form is easy to apply and can be easily understood by patients, we believe that it is suitable for use in samples with different sociodemographic characteristics. It is considered to be appropriate to assess patients' satisfaction regarding the nursing care received during the hospital stay. However, when the purpose is to assess other structure factors such as the comfort/cleanliness of the facilities, the quality of the meals, the relationship/communication/satisfaction with the performance of other health professionals, which is a more comprehensive study, the results seem to be unclear and lack differentiation. Therefore, we suggest some caution in its use.

We recommend the development of other studies on this version using CFA to assess its psychometric properties, so as to validate these results and improve the validity and reliability of the measurement instrument.

\section{References}

Damásio, B., Machado, W., \& Silva, J. (2011). Estrutura factorial do Questionário de Saúde Geral (QSG-12) em uma amostra de professores escolares. Avaliação Psicológica, 10(1), 99-105. Retrieved from http://pepsic.bvsalud.org/pdf/avp/v10n1/ v10n1a11.pdf

Donabedian, A. (2003). An introduction to quality assurance in bealth care. New York, USA: Oxford University Press.

Fernandes, I., Seco, R., \&. Queirós, P. (2009). Os comportamentos de cuidar dos enfermeiros na perspectiva dos utentes. Revista Investigação em Enfermagem, 19, 39-52.

Ferreira, M., Pontes, M., \& Ferreira, N. (2009). Cuidar em enfermagem: Percepção dos utentes. Revista da Faculdade 
de Ciências da Saúde, 6, 358-366. Retrieved from http:// bdigital.ufp.pt/bitstream/10284/1288/1/358-366_FCS_06_. pdf

Ferreira, P. A. (2011). Enfermagem em cardiologia (Tese de doutoramento). Universidade de Coimbra, Portugal.

Grove, S., Burns, N., \& Gray, J. (2013). The practice of nursing research $\left(7^{\text {th }}\right.$ ed.). River Port Lane, USA: Elsevier.

Hill, M., \& Hill, A. (2009). Investigação por questionário (2ª ed.). Lisboa, Portugal: Sílabo.

Laros, J. A. (2005). O uso da análise fatorial: Algumas diretrizes para pesquisadores. In L. Pasquali (Org.), Análise fatorial para pesquisadores (pp. 163-184).

Macedo, L., Moreira, R., \& Moreira, F. (Maio de 2012). Ganhos em saude em doentes submetidos a cirurgia cardíaca. Revista da Ordem dos Enfermeiros, 41, 22-23.

Marôco, J. (2011). Análise estatística com o SPSS Statistics (5a ed.). Pêro Pinheiro, Portugal: Report Number.

Marôco, J. (2014). Análise de equações estruturais: Fundamentos teóricos, Software e aplicações ( $2^{\mathrm{a}}$ ed.). Pêro Pinheiro, Portugal: Report Number.

Marôco, J., \& Garcia-Marques, T. (2006). Qual a fiabilidade do Alfa de Cronbach?: Questões antigas e soluções modernas? Laboratório de Psicologia, 4(1), 65-90. Retrieved from http:// publicacoes.ispa.pt/index.php/p/article/viewFile/763/706

Paz, E., Parreira, P., Lobo, A., Palasson, R., \& Farias, S. (2014). Adaptação transcultural do questionário de satisfação com os cuidados primários de saúde. Acta Paulista de Enfermagem, 27(5), 419-426. doi: 10.1590/1982-0194201400070

Pereira, M., Araújo-Soares, V., \& McIntyre, T. (2001). Satisfação do utente e atitudes face aos médicos e medicina: Um estudo piloto. Psicologia, Saúde \& Doenças, 2(2), 69-80. Retrieved from http://www.scielo.mec.pt/pdf/psd/v2n2/v2n2a05.pdf

Pestana, M., \& Gageiro, J. (2008). Análise de dados para ciências sociais: A complementaridade do SPSS ( $2^{\mathrm{a}}$ ed.). Lisboa, Portugal: Edições Sílabo.

Porter, M., Pabo, E., \& Lee, T. (2013). Redesigning primary care: A strategic vision to improve value by organizing around patients' needs. Health Affairs, 32(3), 516-525. doi: 10.1377/ hlthaff.2012.0961

Ribeiro, A. (2003). Satisfação dos utentes com os cuidados de enfermagem: Construção e validação de um instrumento de medida (Dissertação para concurso de provas públicas Professor Coordenador). Escola Superior de Enfermagem do Porto, Portugal.

Silva, E. (2013) Ganbos em satisfação face aos cuidados de enfermagem de reabilitação: Doentes dependentes (Dissertação de mestrado). Escola Superior de Enfermagem do Porto, Portugal.

Varandas, M., \& Lopes, A. (2012). Formação profissional contínua e qualidade dos cuidados de enfermagem: A necessidade de uma mudança de paradigma educativo. Revista Lusófona de Educação, 22, 141-158. Retrieved from http://www.scielo. mec.pt/pdf/rle/n22/n22a09.pdf 
